\title{
Haematological evaluation in rats following administration of some antisickling agents
}

\author{
O. I. OYEWOLE ${ }^{1 *}$, S. O. MALOMO ${ }^{2}$ and R. O. ARISE ${ }^{2}$ \\ ${ }^{1}$ Department of Biochemistry, Bowen University I W O, Nigeria. \\ ${ }^{2}$ Department of Biochemistry, University, Ilorin, Ilorin, Nigeria. \\ * Corresponding author, E-mail: ioluoye@yahoo.com, Tel: +2348066808560
}

\begin{abstract}
The effect of oral administration of thiocyanate, tellurite and hydroxyurea on haematological profile in albino rats was investigated in this study. Rats were divided into four groups. Control group received distilled water while the three experimental groups were administered with each of the antisickling drug daily at their therapeutic dose for a period of 28 days. All the drugs significantly increased packed cell volume (PCV), haemoglobin concentration $(\mathrm{Hb})$ and mean corpuscular volume (MCV) in the blood of the rats in vivo. Hydroxyurea and thiocyanate caused significant reduction in red cell distribution width (RDW), platelets count and reticulocytes. Tellurite significantly reduced $(\mathrm{P}<0.05)$ red blood cell count $(\mathrm{RBC})$ and mean corpuscular haemoglobin concentration (MCHC) while platelets and reticulocytes were significantly elevated by the drug. In addition, hydroxyurea significantly reduced white blood cell count (WBC) in the rat's blood while thiocyanate caused a reduction in blood $\mathrm{pH}$. These results revealed some information on the positive and negative effects of the drugs on blood parameters which is useful in considering their suitability for the treatment of sickle cell disease.
\end{abstract}

(C) 2009 International Formulae Group. All rights reserved.

Keywords: Haematological profile, Hydroxyurea, Sodium thiocyanate, Potassium tellurite, Sickle cell disease.

\section{INTRODUCTION}

Sickle cell disease $(\mathrm{SCD})$ is a blood disorder characterized by constant red blood cell sickling with resulting haemolytic anaemia and reduction in the number of red blood cell in the patient to about half of that found in normal individual (Wang, 2004). Persons affected with the disease suffer multiple and severe complications which include retarded growth, periodic attacks of pain from blood stasis, bone changes, neurological problems, and progressive kidney dysfunction (Preboth, 2000). The complications are due to blockage of the capillary beds in various organs by masses of sickled red blood cells which may make the patient go into shock (Okpala et al., 2002). Death from anaemia, infections, or ultimately from heart or kidney failure often occurs before the age of 35-40 years (Quinn, 2004).
The disease is also characterized by elevated white blood cell, increased platelets count, decreased MCV, increased MCHC and increased reticulocytes which arise due to erythrocyte destruction (Long and Wilmott, 2006). Blood transfusion has been employed as one of the clinical approaches in both prophylactic and symptomatic treatment of the painful crisis, however, multiple blood transfusions was found to result in several unwanted complications (Wang et al., 2005).

Administration of folic acid, vitamins $\mathrm{B}_{6}$ and $\mathrm{B}_{12}$ were also employed to manage episodes of chronic anaemia in sickle cell patients. Patients taking the vitamins had significant improvement in their haematocrit but blood abnormalities and impaired growth rate associated with the disease were not improved (Ohnishi et al., 2000). Nutritional supplements with iron and fish oil 
supplements were also reported to reduce the severity of anaemia (Ohnishi et al., 2000). However laboratory tests showed that the improvement in anaemia was slight and considered insignificant and that these supplements may even increase the symptoms of the disease (Redding-Lallinger, 2006).

Thiocyanate, tellurite and hydroxyurea are among several chemical compounds reported to prevent sickling of red blood cell and thereby help in ameliorating the painful crisis associated with sickle cell disease (Oyewole et al., 2008). This study intends to investigate and compare the positive and negative effect of the drugs on haematological profile of experimental rats so as to further understand their in vivo mechanism of action and toxicity.

\section{MATERIALS AND METHODS}

Experimental animals and fine chemicals

A total of twenty four male albino rats (Rattus novergicus) of the Wistar strain weighing between 110-120 g were obtained from the Animal House, Department of Physiology, University of Ibadan, Nigeria. They were kept in ventilated cages and allowed to acclimatize for two weeks prior to drug administration. Hydroxyurea was obtained from British Drug House (Chemicals) Ltd., Poole England. Sodium thiocyanate and potassium tellurite salts were products of Hopkins and Williams Ltd. Essex, England.

\section{Drug administration and collection of blood from rats}

The rats were randomly divided into four experimental groups (six in a group). Group A which served as the control received distilled water while the three experimental groups received the therapeutic doses of the respective drugs daily (group B: $15 \mathrm{mg} / \mathrm{kg}$ hydroxyurea, group C: $0.1 \mathrm{mg} / \mathrm{kg}$ potassium tellurite, group D: $10 \mathrm{mg} / \mathrm{kg}$ sodium thiocyanate). The drugs were dissolved in distilled water and administered orally to rats by the use of canular. Rat feed and water were given to the rats ad libitum throughout the experimental period. They were sacrificed after 28 days and their blood collected into EDTA coated bottles to prevent clotting.
Measurement of haematological parameters

Haemoglobin concentration, PCV, RBC count, MCV, MCHC, RDW, WBC count, reticulocytes count and platelets count were determined using the automated blood analyser SYSMEX KX21, a multi-parameter blood cell counter as described by Dacie and Lewis (1991). Fifty microlitres of blood samples were introduced into the equipment and it automatically employ the differences in characteristics possessed by each of the blood components to distinguish and estimate them. Whole blood $\mathrm{pH}$ was determined using Jenway pH meter N-512 connected with ERH 111 electrode.

\section{Statistical analysis}

Data was analyzed using Duncan multiple range test following one-way analysis of variance (ANOVA) using SPSS 10.0 computer software package (SPSS Inc; Chicago, U.S.A). Differences at $\mathrm{P}<0.05$ were considered significant.

\section{RESULTS AND DISCUSSION \\ $P C V, H b$ concentration and $R B C$ count}

Hydroxyurea, thiocyanate and tellurite significantly increased $(\mathrm{P}<0.05)$ the $\mathrm{PCV}$ and $\mathrm{Hb}$ concentration in the blood of the rats compared with the control as shown in Table 1. Tellurite significantly reduced RBC count but this blood parameter was not affected in rats treated with hydroxyurea and thiocyanate. The significant increase in PCV and $\mathrm{Hb}$ concentration by the three drugs suggests a net beneficial effect on erythropoiesis which may be of benefit to sickle cell patients. Sickle cell patients show a significant decrease in their haematocrit $(\mathrm{PCV})$ and $\mathrm{Hb}$ concentration compared to normal individual resulting in severe anaemia (Platt et al., 1994). These low haemoglobin and haematocrit has been attributed to destruction of sickle red blood cells by the phagocytes of the body immune system in the circulating blood system (Long and Wilmott, 2006). The significant decrease in RBC population by tellurite may lead to a state of mild anaemia and a reduction in oxygen carrying capacity of the blood.

\section{MCV, MCHC and RDW}

All the drugs significantly elevated $(\mathrm{P}<0.05) \mathrm{MCV}$ of the blood when compared 
Table 1: Haematological parameters in rats administered with hydroxyurea, tellurite and thiocyanate for 28 days.

\begin{tabular}{lcccc}
\hline Parameters & Control & Hydroxyurea & Tellurite & Thiocyanate \\
\hline PCV $(\%)$ & $21.20 \pm 0.16$ & $24.40 \pm 2.48^{*}$ & $24.15 \pm 2.10^{*}$ & $24.26 \pm 2.24^{*}$ \\
Hb Conc. $(\mathrm{g} / \mathrm{dl})$ & $12.10 \pm 1.37$ & $13.55 \pm 2.50 *$ & $13.38 \pm 2.44^{*}$ & $13.75 \pm 2.41^{*}$ \\
RBC Count $\left(10^{12} / \mathrm{L}\right)$ & $5.55 \pm 0.13$ & $5.52 \pm 0.09$ & $4.74 \pm 0.12^{*}$ & $5.60 \pm 0.12$ \\
MCV $(\mathrm{fl})$ & $69.70 \pm 3.00$ & $80.99 \pm 5.14^{*}$ & $82.18 \pm 3.16^{*}$ & $80.36 \pm 4.33^{*}$ \\
MCHC $(\mathrm{g} / \mathrm{dl})$ & $26.40 \pm 3.50$ & $26.70 \pm 2.44^{*}$ & $21.57 \pm 1.51^{*}$ & $27.10 \pm 2.37$ \\
RDW $(\%)$ & $16.50 \pm 2.43$ & $13.92 \pm 1.56^{*}$ & $18.60 \pm 2.10^{*}$ & $14.11 \pm 1.98^{*}$ \\
WBC Count $\left(10^{9} / \mathrm{L}\right)$ & $11.40 \pm 1.27$ & $9.80 \pm 1.31^{*}$ & $12.00 \pm 1.16$ & $11.80 \pm 1.17$ \\
Platelets $\left(10^{9} / \mathrm{L}\right)$ & $484.0 \pm 10.0$ & $404.0 \pm 8.9^{*}$ & $556.0 \pm 10.6^{*}$ & $408.0 \pm 9.8^{*}$ \\
Reticulocytes $(\%)$ & $13.00 \pm 1.07$ & $10.23 \pm 1.00^{*}$ & $15.47 \pm 1.10$ & $10.40 \pm 1.08^{*}$ \\
Blood pH & $7.28 \pm 0.02$ & $7.30 \pm 0.02$ & $7.26 \pm 0.03$ & $7.02 \pm 0.01^{*}$ \\
\hline
\end{tabular}

Values are Mean $\pm \mathrm{SD}, \mathrm{n}=6$. *Values are significantly different from the control group at $\mathrm{p}<0.05$. PCV=Packed cell volume, $\mathrm{Hb}$ Conc=Haemoglobin concentration, RBC Count=Red blood cell count, MCV=Mean corpuscular volume, MCHC=Mean corpuscular haemoglobin concentration, RDW=Red cell distribution width, WBC=White blood cell count.

with the control. In addition, tellurite significantly decreased the MCHC while hydroxyurea and thiocyanate had no significant effect on blood MCHC. Hydroxyurea and thiocyanate significantly reduced RDW while it was elevated by tellurite. The observed significant increase in $\mathrm{MCV}$ in vivo by the three drugs and the significant reduction in MCHC by tellurite are synonymous with red blood cell hydration which indicated their ability to alleviate sickle cell disease (Brugana et al., 1986). Antisickling agents that increase MCV and or decrease MCHC markedly delay the rate of polymerization of deoxyhaemoglobin and inhibit red blood cell sickling (Malomo and Oyewole, 2008).

The significant reduction in RDW by thiocyanate and hydroxyurea is indicative of their positive haematopoietic activity and their ability to maintain red blood cell standard size. RDW is a measure of anisocytosis (variation in size of the red blood cells) and its elevation reflects active erythropoiesis. Sickle cell anaemia causes a significant variation in cell size and elevation of RDW (Mohandas and Evans, 1989). Haemolytic anaemia and other conditions that cause more immature cells which are of larger size to be released into the bloodstream also increase the RDW.

\section{White blood cell count}

Hydroxyurea significantly reduced WBC count but this parameter was not affected in the blood of rats treated with thiocyanate and tellurite. The observed decrease in total WBC count by hydroxyurea suggests that the drug may be immunosuppressive. This reduction could be due to their diminished production, redistribution from peripheral blood into the tissues or rapid destruction of WBC (Debaun, 2005). Hydroxyurea has been reported to nitrosate haemoglobin and other proteins (Steinberg, 2005), thus the reduction in WBC production could arise from the drug binding to some proteins which has been reported to regulate the proliferation, differentiation and maturation of committed stem cells responsible for the production of WBC (Debaun, 2005). This reduction in WBC by hydroxyurea is however beneficial to SCD patients because most of them have high WBC count which result in production of injurious cytokinins and may cause tissue damage. It was demonstrated that a positive statistical association exist between painful crisis in SCD patients and leucocytes counts (Okpala et al., 2002)

\section{Platelets count}

Hydroxyurea and thiocyanate significantly decreased $(\mathrm{P}<0.05)$ blood platelet count in the rats while tellurite caused an increase compared with control. The observed significant reduction in platelets count by hydroxyurea and thiocyanate is indicative of their in vivo antisickling potential. Most SCD patients normally have increased platelets count which has been reported to be one of the promoters of vaso-occlusion experienced by patients during crisis (Francis and Johnson, 
1991). The significant increase in platelet count caused by tellurite may not be beneficial to SCD patients as it may promote vasoocclusion and also cause heart block in patient treated with this drug (Boyd et al., 2006).

\section{Reticulocytes}

Hydroxyurea and thiocyanate significantly decreased the percentage reticulocytes in the blood of rats but tellurite increased this blood parameter. The significant reduction in percent reticulocytes following administration of thiocyanate and hydroxyurea is an evidence of decreased haemolysis and increased life span of RBC induced by the two drugs. Carbamylation of haemoglobin by thiocyanate and stimulation of $\mathrm{HbF}$ production by hydroxyurea administration has been reported to prolong life span of haemoglobin (Mehta et al., 2006). On the other hand, the increase in reticulocytes production by tellurite is an evidence of increased haemolysis and shortened red blood cell life span caused by the drug (Long and Wilmott, 2006).

\section{Whole blood pH}

As regards blood $\mathrm{pH}$, thiocyanate caused its significant reduction from 7.28 in the control group to 7.02 while tellurite and hydroxyurea had no effect on blood $\mathrm{pH}$. The observed reduction in extracellular $\mathrm{pH}$ caused by thiocyanate suggests that the drug might increase the efficiency of oxygen transport by haemoglobin. Low $\mathrm{pH}$ (high $\mathrm{H}^{+}$concentration) has been shown to enhance oxygen delivery to tissues due to increase release of haemoglobin-bound oxygen (Brugana et al., 1989). This $\mathrm{pH}$ reduction by thiocyanate is beneficial to SCD patients as more oxygen is release to their tissues even at low oxygen tension. This reduction in $\mathrm{pH}$ might result due to carbamylation of haemoglobin by thiocyanate, a chemical modification which produces more $\mathrm{H}^{+}$within the erythrocyte (Brugana et al., 1989).

\section{Conclusion}

Results obtained in this study indicated that the three antisickling drugs have positive effects on haematopoiesis in the blood of the rats following their administration. However tellurite may increase red blood cell haemolysis which can aggravate the condition of sickle cell patients. Hydroxyurea may be immunosuppressive as it reduced white blood cell count while the significant reduction in blood $\mathrm{pH}$ caused by thiocyanate may affect acid base balance in the blood.

\section{REFERENCES}

Boyd JH, Strunk RC, Morgan WJ. 2006. The outcomes of sickle cell disease in adulthood are clear, but the origin and progression of sickle cell anaemiainduced problems in the heart and lung in childhood are not. J. Pediatr., 149: 3-4.

Brugana C, Bunn HF, Tosteson DC. 1986. Regulation of erythrocyte cation and water content in sickle cell anaemia. Science, 232: 388-390.

Brugana C, Van Ha T, Tosteson DC. 1989. Acid $\mathrm{pH}$ induced formation of dense cells in sickle erythrocyte. Blood, 74: 487490.

Dacie JV, Lewis SM. 1991. Practical Haematology $\quad\left(7^{\text {th }} \quad\right.$ edn $) . \quad$ Churchill Livingstone: Edinburgh; 1228-1234.

Debaun MR. 2005. Hydroxyurea as secondary prevention for stroke in children with sickle cell anaemia. J. Pediatr., 147: 560561.

Francis RB Jnr, Johnson CS. 1991. Vascular occlusion in sickle cell disease: current concepts and unanswered questions. Blood, 77: 1405-1414.

Long SS, Wilmott RW. 2006. Exchange transfusion for first stroke associated with sickle cell anaemia. J. Pediatr., 149: 1-9.

Malomo SO, Oyewole OI. 2008. Cations content and membrane properties of human sickle blood incubated with hydroxyurea, tellurite and thiocyanate. Egypt. J. Biochem. Mol. Biol., 26(1): 117125.

Mehta SR, Afenyi-Annah A, Byrns PJ. 2006. Opportunities to improve outcomes in sickle cell disease. Am. J. Family Physicians, 74(2): 303-310.

Mohandas N, Evans E. 1989. Rheology and adherence properties of sickle cells: Potential contribution to haematologic manifestation of the disease. Ann. NY Acad. Sci., 565: 327-337.

Ohnishi ST, Ohnishi T, Ogunmola GB. 2000. Sickle cell anemia: a potential nutritional approach for a molecular disease. Nutrition, 16: 330-338. 
Okpala I, Daniel Y, Haynes R, Odoemene D, Goldman J. 2002. Relationship between the clinical manifestations of sickle cell disease and the expression of adhesion molecules on white blood cells. Eur. J. Haem., 16: 135-144.

Oyewole OI, Malomo SO, Adebayo JO. 2008. Comparative studies on antisickling properties of thiocyanate, tellurite and hydroxyurea. Pak. J. Med. Sci., 24(1): 1822.

Platt OS, Brambilla DJ, Rosse WF, Milner PF, Castro O, Steinberg MH, Klug P. 1994. Mortality in sickle cell disease: life expectancy and risk factors for early death. N. Engl. J. Med., 330: 163-166.

Preboth M. 2000. Management of pain in sickle cell disease. Am. J. Family Physicians, 1544: 1549-1590.
Quinn CT, Rogers ZR, Buchanan GR. 2004. Survival of children with sickle cell disease. Blood, 103: 4023-4027.

Redding-Lallinger R. 2006. Questions in the management of sickle cell. J. Pediatr., 149: 595-597.

Steinberg MH. 2005. Sickle cell disease and hydroxyurea: the good, the bad and the future. Blood, 105: 441-444.

Wang WC. 2004. Sickle cell anaemia and other sickling syndrome. In Wintrobes Clinical Haematology $\left(11^{\text {th }}\right.$ edn). Philadelphia; 1264-1311.

Wang WC, Morales KH, Scher CD, Styles L. 2005. Effect of long term transfusion on growth in children with sickle cell anaemia: result of the Stop trial. J. Paed., 147: 244-247. 